\title{
Variation of TTC Repeat Pattern In The Dna of Mycobacterium Leprae Isolates Obtained from Archeological Bones and Leprosy Patients From East Nusa Tenggara
}

\author{
Dinar Adriaty ${ }^{1 *}$, Ratna Wahyuni, Iswahyudi ${ }^{1}$, Bimo Aksono ${ }^{1}$, \\ Toetik Koesbardiati ${ }^{2}$, Indropo Agusni ${ }^{1}$, Shinzo Izumi ${ }^{1}$ \\ ${ }^{1}$ Leprosy Study Group, Institute of Tropical Disease, Airlangga University, Surabaya, Indonesia \\ ${ }^{2}$ Antropology Department, Social and Politics Faculty, Airlangga University, Surabaya, Indonesia
}

\section{ABSTRACT}

The existence of leprosy or kusta or Morbus Hansen or Hansen's disease has been known for years, including in Indonesia. Starting from the discovery of Mycobacterium leprae isolates from ancient bone (about 1.000 years B.C), the archaeological excavations results in East Nusa Tenggara, interesting questions arise about how the development of leprosy in eastern Indonesia is. Biology molecular study would become a powerful tool to investigate the presence of leprosy bacillary whether there are similarities between the genomes of $M$. leprae isolates in the primeval and the present. PCR examinations were performed on mandibular bone fragments from ancient human who lived 1000 years B.C. discovered in archaeological surveys on the island of Lembata and three leprosy patients from East Nusa Tenggara. The DNA extraction was performed using a kit from Qiagen products and its TTC repeating pattern was seen with the method of direct sequencing. It turned out that the TTC profile obtained from samples of archaeological was as many as 13 copies, while the repetition of TTC in three samples of leprosy patients were 15, 17 and 26 copies. The different number of TTC repetition shows the different isolates of $M$. leprae between in the ancient times and the present. Further studies are needed to verify the differences in the genome that occur, for example from the study of SNPs (single nucleotide polymorphisms).

Keywords: Leprosy, TTC repeat, M. leprae, Archaeology, East Nusa Tenggara

\section{INTRODUCTION}

Leprosy is an ancient disease which has been spread among human populations by migrations, military expansion and colonization, as well as along trade routes $[1,2]$. According to the history, the disease of leprosy entering Indonesia was allegedly carried away from China and India to the island of Java. In 1927 in Platungan near Semarang stands the first leprosaria in Indonesia; and, in 1928 the beginning of leprosy elimination has started and was pioneered by Dr. J.B. Sitanala [3].

East Nusa Tenggara was the region that was famous for its discovery of hobbits or dwarf humans (Homo floresiensis). It has been suspected that they were derived from ancient region that stood alone and did not become a

\footnotetext{
*Corresponding address:

Dinar Adriaty

Leprosy Study Group, Institute of Tropical Disease, Airlangga

University, Jl. Mulyorejo, Surabaya, Indonesia 60115

Phone : +62-31-5992445-6, E-mail : ddriaty@yahoo.co.id
}

part of the continent or other large island in the world [4]. Hopefully, if bacillary disease of leprosy found in that islands, it could mean that Mycobacterium leprae isolates are native bacteria of the territory of Indonesia and it can become one of the reasons why in the eastern part of Indonesia the incident rate and prevalence rate of leprosy tend to get high until now [5]. In order to study those problems, molecular typing would be a great value to study the transmission pattern and geographical distributions of $M$. leprae for epidemiological investigation.

The purpose of this research is to detect the presence of $M$. leprae genomes in the primeval and the present by analyzing the variation number of TTC repetition in the archeological samples and some of leprosy patients in East Nusa Tenggara. It has been possible to recognize potential polymorphic sites from the genome sequence of $M$. leprae. As is the case in several eukaryotic and prokaryotic genomes that have been sequenced, short stretches of DNA that occur in tandem repetitions are also found in $M$. 
leprae [6]. Matsuoka [7] first reported that 6-bp sequence (GACATC) was found as two alleles in the rpoT gene of M.leprae. This was followed by the recognition of variable number tandem repetitions (VNTRs) of the TTC triplet in a noncoding region of the $M$. leprae cosmid MLCB2407 (GenBank accession no. AL023596) [8]. According to the report from Shin [9], the gene location of the TTC repetitions were not found in Mycobacterium tuberculosis, Mycobacterium avium, Mycobacterium marinum, or human tissues, which indicated their specificity to $M$. leprae. Truman [10] also reports the stability of the TTC (VNTRs) by testing this gene from $M$. leprae that was obtained from armadillo and nude mice tissues being investigated for 121 months. Thus, this gene is reliable as a marker of strain differentiation for epidemiological investigations of leprosy.

\section{MATERIALS AND METHODS}

\section{Mycobacterium Leprae Isolates and Preparation of Genomic DNA}

Archeological Sample. Skeletal bone was derived from Lewoleba, Lembata Island, excavated in the Dutch era. Estimated bone was 1000 year B.C according to the Carbon14 examination (age activity according to $2990+/$ 160BP) [11] methods. The sex of this skeleton was assessed as female on the basis of cranial morphologies. The dental and skeletal evidences suggested that the age of death was at an early aged in the range of 20-25 years-old. A piece of mandible bone was grinded to perform the powder. Bone powder was weighed of $0.25 \mathrm{gram}$ to extract by the DNA extraction kit. The DNA extraction method was Qiagen:DNeasy tissue kit (Qiagen, Valencia, CA). A bone, which had been placed on the $2 \mathrm{ml}$ sterile tube, was added with $200 \mathrm{uL}$ lysis buffer containing $20 \mathrm{uL}$ proteinase$\mathrm{K}$ and $180 \mathrm{uL}$ ATL buffer. The specimen was vortexed and incubated at $55^{\circ} \mathrm{C}$ until the bone powder was completely digested (it took overnight), then the rest of the procedure was described as in the manufacturer's protocol. Pure DNA was stored at $4^{\circ} \mathrm{C}$.

Slit-skin Specimens. The samples were obtained from leprosy patients that came in the peripheral health center in East Nusa Tenggara region during 2011. All patients collected were local villagers categorized as Multibacillary (MB) or Pausibacillary (PB) cases based on the criteria set by WHO (World Health Organization). Slitskin Smear specimens were collected from the skin lesion of patient in the same manner as the routine slit-skin smear test for Bacterial Index examination. The samples on the disposable surgical blade were soaked into PhosphateBuffered Saline and kept in a freezer until use. The bacilli were removed from the blade and collected as a pellet by centrifugation at $16,000 \mathrm{~g}$ for $20 \mathrm{~min}$ in $4^{\circ} \mathrm{C}$ until served and, then, were washed with phosphate-buffered saline during the isolation. The DNA extraction method used Qiagen:DNeasy tissue kit.

\section{Mycobacterium leprae Detection}

The $M$. leprae gene in regio RLEP3 repetitive element (X17153) was chosen to be amplified with nested PCR. Amplification will produce about 129 bp for external (outer) and 99 bp for internal (inner) product. PCR was carried out using a Premix $G$ mixture of FailSafe PCR System Cat. No. FSP995G (EPICENTRE, Madison, WI, USA) in a $20 \mu \mathrm{l}$ volume of reaction mixture containing at least $0.1 \mathrm{pg}$ of genomic DNA in $2 \mu$ l of template DNA solution and $2 \mu \mathrm{l}$ of $5 \mu \mathrm{M}$ primers using FailSafe PCR Enzyme Taq Mix 250 U@2.5 U/ $\mu$ l Cat. No. FS99250. Primers Lp1 5' TGCATGTCATGGCCTTGAGG 3' and Lp2 5' CACCGATACCAGCGGCAGAA 3' were produced by Takara (Japan) and the amplification was done in a thermal cycler machine (BioRad i-cycler) under the conditions of $2 \mathrm{~min}$ at $98{ }^{\circ} \mathrm{C}$ for preheating, $20 \mathrm{sec}$ at $98^{\circ} \mathrm{C}$ for denaturation, $30 \mathrm{sec}$ at $56^{\circ} \mathrm{C}$ for annealing and $30 \mathrm{sec}$ at $72{ }^{\circ} \mathrm{C}$ for elongation repeated for 35 cycles followed by prolonged extension of $5 \mathrm{~min}$ at $72{ }^{\circ} \mathrm{C}$, then inactivation at $4{ }^{\circ} \mathrm{C}$. Amplicon was, then, being nested with primers Lp3 5' TGAGGTGTCGGCGTGGTC 3' and Lp4 5' CAGAAATGGTGCAAGGGA 3' under the conditions of $2 \mathrm{~min}$ at $98{ }^{\circ} \mathrm{C}$ for preheating, $20 \mathrm{sec}$ at $98{ }^{\circ} \mathrm{C}$ for denaturation, 30 sec at $56^{\circ} \mathrm{C}$ for annealing and $30 \mathrm{sec}$ at $72{ }^{\circ} \mathrm{C}$ for elongation repeated for 30 cycles followed by prolonged extension of $5 \mathrm{~min}$ at $72{ }^{\circ} \mathrm{C}$, then inactivation at $4{ }^{\circ} \mathrm{C}$. The full length of this amplicon was separated by electrophoresis in 3\% HS agarose gel Code No. 312-01431 (Cambrex Bioscience, Rockland, ME, USA) using TBE (Tris-Boric-EDTA, pH 8.0) buffer at $100 \mathrm{~V}$. All the positives samples were continued to genotyping analysis.

\section{Genotyping of TTC Repetitions}

PCR was carried out as described before and was made in a $50 \mu \mathrm{l}$ volume of reaction mixture containing at least $0.1 \mathrm{pg}$ of genomic DNA in $5 \mu \mathrm{l}$ of template DNA solution and $2 \mu \mathrm{l}$ of $5 \mu \mathrm{M}$ primers. Primers TTC-A (5'GGACCTAAACC- 
ATCCCGTTT3') and TTC-B (5'CTACAGGGGGCACTTAGCTC3') were used for amplification and PCR will produce about 200bp amplification product. The amplification was done in a thermal cycler machine (BioRad icycler) under the conditions of $2 \mathrm{~min}$ at $98{ }^{\circ} \mathrm{C}$ for preheating, $20 \mathrm{sec}$ at $98{ }^{\circ} \mathrm{C}, 30 \mathrm{sec}$ at $58{ }^{\circ} \mathrm{C}$, $30 \mathrm{sec}$ at $72^{\circ} \mathrm{C}$ for 40 cycles followed by prolong extention of $5 \mathrm{~min}$ at $72{ }^{\circ} \mathrm{C}$, then inactivation at $4{ }^{\circ} \mathrm{C}$. The full length of this amplicon was separated by electrophoresis in 3\% NuSieve GTG agarose gel Cat No. 50080 (Cambrex Bioscience, Rockland, ME, USA) using TAE (Tris-Acetate-EDTA, pH 8.0) buffer at $100 \mathrm{~V}$.

The numbers of TTC repetitions were confirmed by direct sequencing. DNA samples for sequencing were recovered by GFX ${ }^{\mathrm{TM}}$ PCR, DNA and Gel Band Purification kits (Amersham Biosciences, GE Healthcare) with product code: 27-9602-01 according to the manufacture's manual. Before sequencing reaction, the quantity and quality of purified DNA were examined by UV spectrophotometer. Dual CyDye Terminator Sequencing kits Cat. No 25-8226-01 (Amersham Biosciences, GE Healthcare) was used in the preparation of sequencing reaction. The mixture for cycle sequencing (labeling) was performed according to the manufacture's manual. The sequencing reaction was also done in a thermal cycler machine (BioRad i-cycler) under the following condition: $20 \mathrm{sec}$ at $95^{\circ} \mathrm{C}, 15$ sec at (TM of sense primer +3$)^{\circ} \mathrm{C}, 1 \mathrm{~min}$ at $70^{\circ} \mathrm{C}$ and repeat for 35 cycles. The sequencing product was, then, purified by ethanol precipitation and dried followed by dissolving it in $2 \mu \mathrm{l}$ of loading dye and was loaded into prepared acrylamide gel in Long-Read Tower ${ }^{\mathrm{TM}}$ System (Amersham Biosciences) Version 3.01. Sequence analysis was done by using Long-Read Tower ${ }^{\mathrm{TM}}$ System (Amersham Biosciences) with the temperature of $60^{\circ} \mathrm{C}$ as described in the protocol.

\section{RESULT AND DISCUSSION}

The materials used in this study were archaeological skeletal that remained excavated from Lewoleba village in Lembata Island during the Dutch era. All skeletal materials are stored in the Department of Pathology and Anatomy, Medical Faculty, Airlangga University in Surabaya, Indonesia, where no other leprous materials were stored [12]. Sterile materials were used for the sampling to avoid possible contamination. The facial cranium of the skeletal showed several typical symptoms of leprosy
$[11,12]$, such as in the rhinomaxillary area, rounding deformation and disappearance of the anterior nasal spine (Fig1.A1).

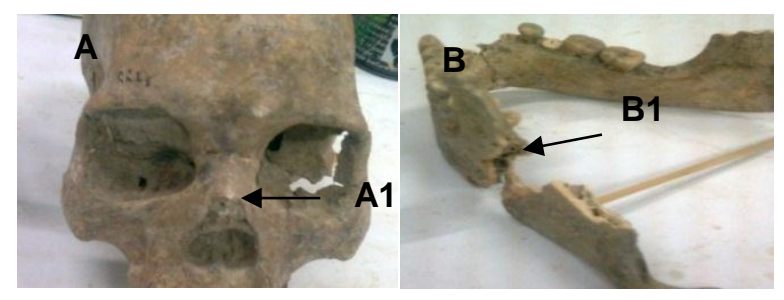

Fig1. Macroscopic view of the skeletal lesion in the skull of archeological sample; A. The skull profile that arrows in panel (A1) disappearance of the anterior nasal spine; B. Location of the DNA extraction, the mandible bone (B1)

There were three isolates collected from the East Nusa Tenggara leprosy patients, and they were all new cases and Multibacillary type. All extracted samples showed positive correlation with primers that were specific to detect M.leprae bacillary (M.leprae gene in regio RLEP3 repetitive element (X17153)), as recommended by Donoghue et.al [13].

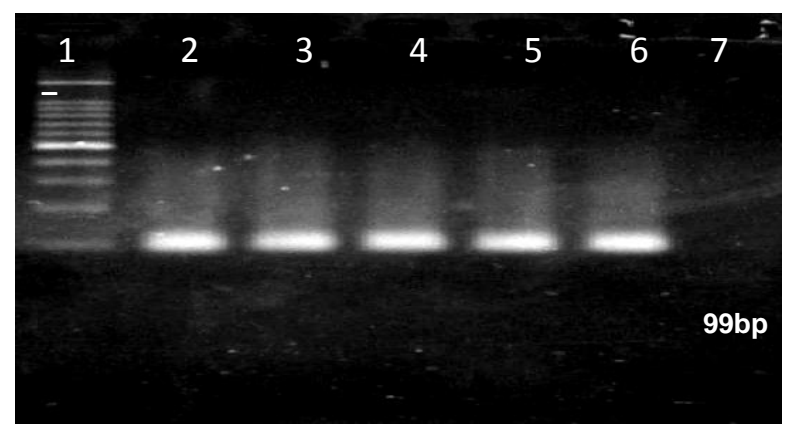

Fig2. PCR Product of M.leprae Detection. Samples were: lane 1, the DNA size marker of 100bp ladder; lane 24, isolates from East Nusa Tenggara villagers; lane 5, Mandible bone powder; lane 6, PC, positive control (M.leprae strain Thai-53); lane 7, NC, negative control

All the positive samples were, then, analyzed by TTC repetitions genotyping. They were amplified by primers recommended by Matsuoka et al [14]. Amplicon has the size of about 200bp. It is for positive control which uses $M$. leprae strain Thai-53. Other samples vary as seen in the figure below. Most TTC genotype in South East Asian region, such as the M. leprae strain Thai-53 from Thailand is TTC-15 copies and from Philippines, is TTC-14copies; it has been reported by Shin et al. that Latin American countries commonly have TTC-10copies which is shorter than in South East Asian as reported by Matsuoka et al. Africa and India have different typing than those two regions in which it is longer-repeated type (M. leprae strain Tamil 
Nadu India has TTC-21 copies; M. leprae strain Ethiopia has T'TC-29 copies).

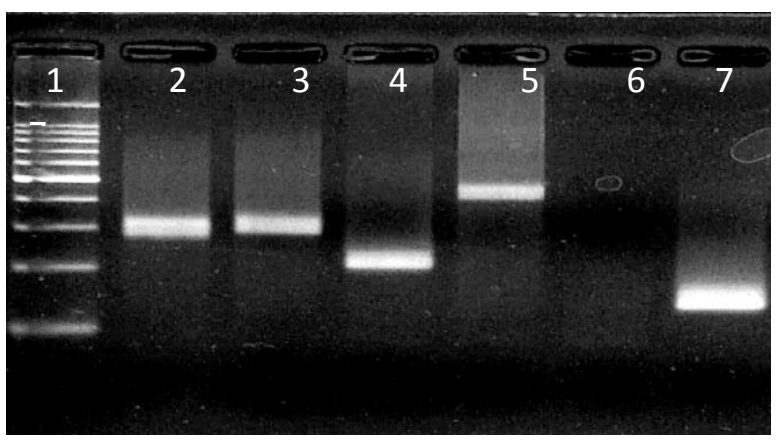

Fig3. PCR Product of TTC repetitions. Samples were: lane 1 , the DNA size marker of $100 \mathrm{bp}$; lane $2-5$, isolates from Mandible bone powder and from East Nusa Tenggara villagers; lane $6, \mathrm{NC}$, negative control; lane 7, PC, positive control (M.leprae strain Thai-53)

Table 1. Result of VNTR genotyping

\begin{tabular}{ll}
\hline M. leprae Isolates & $\begin{array}{l}\text { Polymorphic } \\
\text { locus TTC }\end{array}$ \\
& ML2344-2345 \\
\hline Archeological mandible bone & 13 copies \\
Patient NTT-A & 15 copies \\
Patient NTT-B & 17 copies \\
Patient NTT-C & 26 copies \\
Control M. leprae Thai-53 & 15 copies \\
\hline
\end{tabular}

a $\mathrm{T}=$ thymine, $\mathrm{T}=$ thymine, $\mathrm{C}=$ cytosine

The archeological bone has a short type, that is, 13 T'TC copies. Modern human beings, i.e. leprosy patients in the present day, have longer type, varying from 15 to 26 T'TC copies. It means that the shorter type localized in that island (archeological sample) is more original, and it comes from that area itself than that in the present. Modern human beings have a better mobilization in which the interaction between locals and outsiders within the island is more open than in the ancient time, one reason why the genotype profile varies.

\section{CONCLUSION}

The different number of TTC repetitions shows M. leprae's different isolates in ancient times and the present. Further studies are needed to verify the differences in the genome that occur, such as the study of SNPs (single nucleotide polymorphisms).

\section{ACKNOWLEDGEMENTS}

Our grateful thank to all people and paramedics in Lewoleba village, Lembata Island for all kindness, cooperation and kindly support in this observation.

\section{REFERENCES}

1. Monot M, Honore N, Garnier T, Araoz R, Coppee JY, Lacroix C, Sow S, Spencer JS, Truman RW, Williams DL, Gelber R, Virmond M, Flageul B, Cho SN, Ji B, Mondolfi AP, Convit J, Young S, Fine PE, Rasolofo V, Brennan PJ and Cole ST (2005) On the Origin of Leprosy. Sciencemag. 308: 1040-1042.

2. Taylor GM, Blau S, Mays S, Monot M, Lee OYC, Minnikin DE, Besra GS, Cole ST, Rutland P ( 2009) Mycobacterium leprae genotype amplified from an archaeological case of lepromatous leprosy in Central Asia. J Arch Sc. 36:2408-2414.

3. Departemen Kesehatan RI (2002) Buku Pedoman Pemberantasan Penyakit Kusta. Dirjen PPM dan PL. Jakarta.

4. Brown P, Maeda T (2009) Liang Bua Homo floresiensis mandibles and mandibular teeth : a contribution to the comparative morphology of a new hominin species. J Hum Evol. 57:571-596.

5. Bakker MI, Hatta M, Kwenang A, Klatser PR and Oskam L (2002) Epidemiology of Leprosy on Five Isolated Islands in the Flores Sea, Indonesia. Trop Med and Int Health. 7(9): 780-787.

6. Young SK, Taylor GM, Jain S, Suneetha LM, Sunetha S, Lockwood DNJ and Young DB (2004) Microsatellite Mapping Mycobacterium leprae Population in Infected Humans. J Clin Microbiol. 42: 4931-4936.

7. Matsuoka M, Zhang L, Budiawan T, Saeki K and Izumi S (2004) Genotyping of Mycobacterium leprae on the Basis of the Polymorphism of TTC Repetitions for Analysis of Transmission. J Clin Microbiol. 42(2): 741-745.

8. Matsuoka M, Zhang L, Morris M.F, Legua P and Wiens C (2005) Polymorphism in the rpoT gene in Mycobacterium leprae Isolates Obtained from Latin American Countries and Its Possible Correlation with the Spread of Leprosy. FEMS Microbiol Letters. 243: 311-315.

9. Shin YC, Lee H, Walsh GP, Kim JD and Cho SN (2000) Variable of TTC Repetitions in Mycobacterium leprae DNA from Leprosy Patients and Use in Strain Differentiation. J Clin Microbiol. 38 (12): 537-544.

10. Truman R, Fontes AB, Miranda AB, Suffys P and Gillis T (2004) Genotypic Variation and Stability of Four Variable-Number Tandem Repetitions and Their Suitability for Discriminating Strain of Mycobacterium leprae. J Clin Microbiol. 42: 25582565.

11. Suzuki K, Takigawa W, Tanigawa K, Nakamura K, Ishido Y, Kawashima A, Wu H, Akama T, Sue M, Yoshihara A, Mori S, Ishii N (2010) Detection of Mycobacterium leprae DNA from Archaeological Skeletal Remains in Japan Using 
Whole Genome Amplification and Polymerase Chain Reaction. PLoS ONE. 5(8): e12422.

12. Aksono B, Koesbardiati T, Adriaty D, Wahyuni R, Iswahyudi, Agusni I (2011) Detection and Phylogenetic Analysis of Mycobacterium leprae in Prehistoric skull Bone from Lewoleba, Lembata Island, Indonesia based on TTC regions. Proc. APICA $13^{\text {th }}$ IAA, Int'l congress. Surabaya.

13. Donoghue HD, Marcsik A, Matheson C, Vernon K, Nuorala E, Molto J.E, Greenblatt CL, Spigelman M (2005) Co-infection of Mycobacterium tuberculosis and Mycobacterium leprae in human archaeological samples: a possible explanation for the historical decline of leprosy. Proc R Soc B. 272, 389-394.

14. Matsuoka M, Maeda S, Kai M, Nakata N, Chae GT, Gillis TP, Kobayashi K, Izumi S, Kashiwabara Y (2000) Mycobacterium leprae Typing by Genomic Diversity and Global Distribution of Genotypes. Int J Lepr. 68(2): 122-128. 